\title{
Evaluation of substituted 1,2,3-dithiazoles as inhibitors of the Feline Immunodeficiency Virus (FIV) nucleocapsid protein via a proposed zinc ejection mechanism
}

\author{
Christopher R. M. Asquith ${ }^{[a][b]}$, Lidia S. Konstantinova ${ }^{[c][d]}$, Tuomo Laitinen ${ }^{[e]}$, Marina L. Meli ${ }^{[b]}$, Antti \\ Poso[e], Oleg A. Rakitin ${ }^{[\mathrm{c}][\mathrm{d}]}$, Regina Hofmann-Lehmann ${ }^{[\mathrm{b}]}$, Stephen T. Hilton ${ }^{[\mathrm{a}] *}$
}

\begin{abstract}
A diverse library of 5-thieno-, 5-oxo-, 5-imino-1,2,3dithiazole derivatives was synthesized and evaluated for efficacy against the Feline Immunodeficiency Virus (FIV) as a model for HIV in cells. Several diverse compounds from this series displayed nanomolar activity and low toxicity, representing a potential new class of compounds for the treatment of FIV and HIV.
\end{abstract}

\section{Introduction}

The continual discovery of novel therapeutics against varying strains of both viruses and bacteria is essential due to their ability to adapt and become resistant to current treatments. The human immune deficiency virus (HIV) is a case in point, with an array of drugs used to target multiple points in the viral life cycle but the continual development of resistance by the virus has continued to erode their efficacy. ${ }^{1}$ HIV, which results in the development of Acquired Immunodeficiency Syndrome (AIDS), has caused over 25 million deaths worldwide, with over 34 million people currently infected with $\mathrm{HIV}^{2}$ Amongst non-primate lentiviruses such as HIV-1 and HIV-2, only the Feline Immunodeficiency Virus (FIV) causes a similar compromised immune system as seen in humans, ${ }^{3}$ with several FIV strains also displaying central nervous system involvement and analogous AIDS-type disease progression..$^{4,5}$

The short basic nucleic acid binding nucleocapsid protein (NCp) of HIV and FIV is an under-explored anti-viral target with no clinically used drugs, despite its involvement at multiple points of the viral replication cycle. These include annealing of the cellular primer $\mathrm{tRNA}_{3}{ }^{\text {lys }}$ to the primer binding site in reverse transcrption, ${ }^{6,7}$ promotion of dimerisation, packing and organization of protein-RNA complexes within freshly created virons. ${ }^{8-10}$ The $\mathrm{NCp}$ is an attractive protein target as it has been

[a] Dr. C. R. M. Asquith, Dr. S. T. Hilton

School of Pharmacy, Faculty of Life Sciences

University College London, London, WC1N 1AX, United Kingdom

E-mail: s.hilton@ucl.ac.uk

[b] Dr. C. R. M. Asquith, Dr. M. Meli, Prof. R. Hofmann-Lehmann Clinical Laboratory \& Center for Clinical Studies, Vetsuisse Faculty, University of Zurich, 8057 Zurich, Switzerland

[c] Dr. L. S. Konstantinova, Prof. O. A. Rakitin Zelinsky Institute of Organic Chemistry, Russian Academy of Sciences, Moscow, 119991, Russian Federation

[d] Dr. L. S. Konstantinova, Prof. O. A. Rakitin Nanotechnology Education and Research Center, South Ural State University, Lenina Ave. 76, Chelyabinsk, Russian Federation

[e] Dr. T. Laitinen, Prof. A. Poso

School of Pharmacy, Faculty of Health Sciences,

University of Eastern Finland, Kuopio, 70211, Finland shown to be mutation resistant with inhibition yielding noninfectious virons. ${ }^{6,11}$ It contains a conserved double zinc finger peptide unit $\mathrm{C}-\mathrm{X}_{2}-\mathrm{C}-\mathrm{X}_{4}-\mathrm{H}-\mathrm{X}_{4}-\mathrm{C}(\mathrm{CCHC})$ that is found in nearly all retroviruses with the exemption of spumaviruses, ${ }^{7}$ including HIV$1 / 2,{ }^{12,13}$ FIV ${ }^{14}$ Simian Immunodeficiency Virus (SIV), ${ }^{15}$ Equine Infectious Anemia Virus (EIAV) ${ }^{16}$ amongst others. ${ }^{17}$ The development of an effective agent that could target one or both of these zinc fingers of the nucleocapsid protein would render the virus inert as deletion or modification of either zinc finger leads to virus inactivation. ${ }^{18,19}$

Two different approaches have been utilised towards the development of nucleocapsid inhibitors; the first, based on small molecules that compete with the binding of the substrate RNA nucleic acid chain has met with some success. ${ }^{20,21}$ The second approachis based on the irreversible ejection of the structural $\mathrm{Zn}^{2+}$ ion has been more productive. Key compounds with this mechanism of action are exemplified by compounds 1-8..$^{22-29}$ Common functionalities include a disulphide bridge and more recently a diselenide bridge ${ }^{30}$ and/or a stable electronically deficient core/functional group(s) (Figure 1).
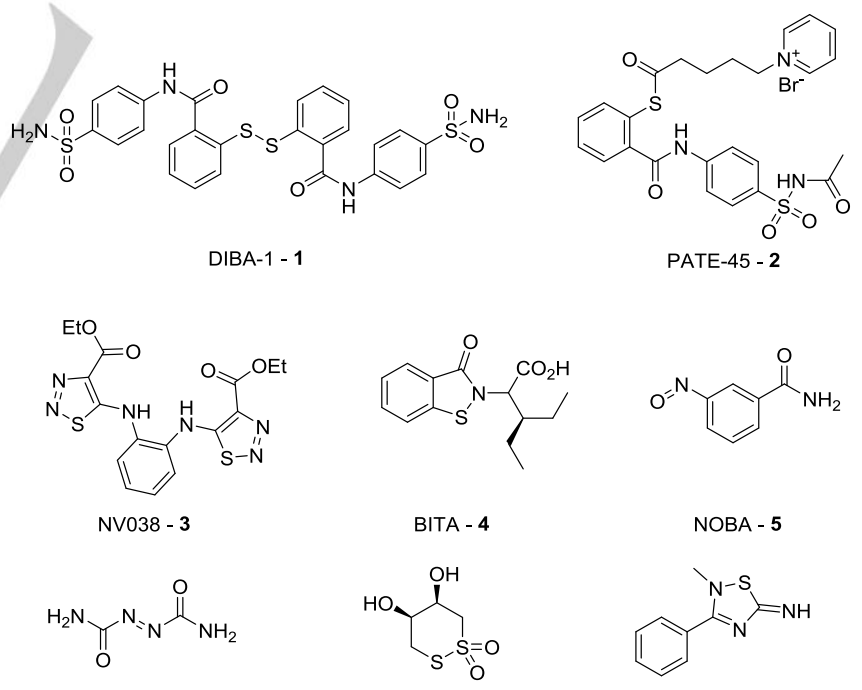

ADA - 6

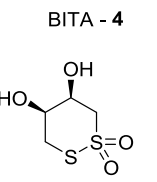

NOBA - 5

Figure 1. Previously reported zinc abstractors in the literature

As part of a longer term program focusing on the development of novel anti FIV/HIV agents that target the NCp via zinc abstraction, exploring the development of novel compound classes. We achieved this using FIV as a surrogate model for HIV; the results of our investigations are reported below. 


\section{Results and Discussion}

In order to develop novel therapeutic agents against the NCp of FIV, we used an in silico homology model derived from HIV-1 and EIAV nucleocapsid proteins to explore heteroatom rich disulphide containing compounds. Building on our previous knowledge relating to bis[1,2]dithiolo[1,4]thiazines and bis[1,2]dithiolopyrrole derivatives ${ }^{31}$ and tetrathiocine derivatives ${ }^{32}$. The 1,2,3-diathiazole core caught our interest as it has been shown to have a broad biological inhibition profile with activities. These properties include anti-bacterial, ${ }^{33-35}$ anti-cancer, ${ }^{37-38}$ anti-fungal//herbicidal ${ }^{39-43}$ and anti-melanin activities. ${ }^{44}$

The 1,2,3-dithiazole scaffold is a stable and has the potential to be substituted at the C-4 and C-5 positions, while containing an electrophilic disulphide bond. Substitutions were made to explore the propensity of the disulphide to react with the cysteine thiolates of the NCp model. Investigation of the alignment and electronic distribution of the 1,2,3-dithiazole core led to a small selection of structurally diverse compounds, which were computationally modelled using Density Functional Theory (DFT) and a small selection of compounds were then synthesized and tested (Figure 2).
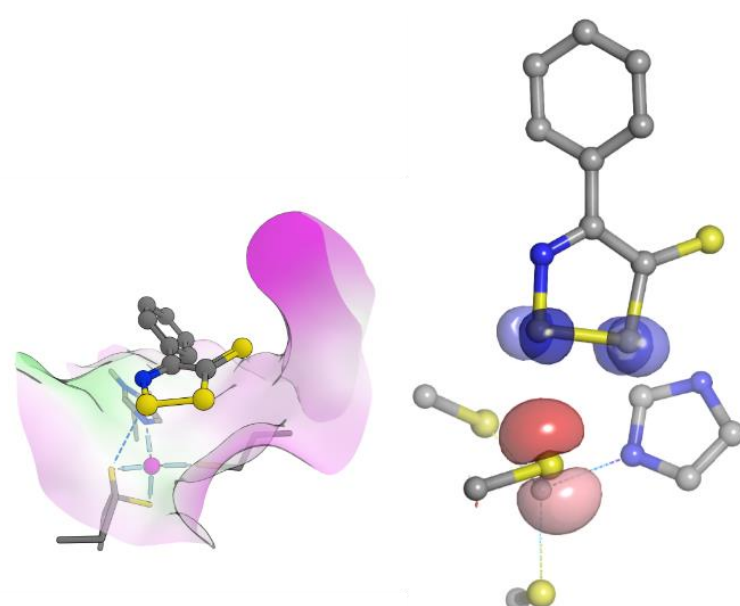

Figure 2. Virtual screening was based on both molecular docking (left) and DFT molecular orbital calculations (right). Molecular docking was used to estimate if the screened compound is able to achieve a suitable docking pose. The DFT calculations were based on the docking poses and thus validated if the frontier orbitals of the reactants are geometrically optimally located or not (HOMO orbitals marked using a red surface and the LUMO-orbitals of blue colored 1,2,3 dithiazole scaffold), (Schrödinger Maestro)

A series of selected 1,2,3-dithiazoles containing a disulphide bridge and our supporting mechanistic rationale demonstrating the potential of this heterocyclic system. These heterocycles pose under-reported in the literature, due to the fact that C-5 substituted derivatives are a relative synthetic challenge. ${ }^{45}$

To date, 1,2,3-dithiazole chemistry has centered around the 4,5-dichloro-1,2,3-dithiazolium chloride salt (Appel Salt) and the susceptibility of attack by nucleophiles at the S-1, S-2, C-4 and C5 atoms. ${ }^{46}$ We anticipated that these synthetic mechanisms to access the core could also potentially play a part in the zinc abstraction mechanism. ${ }^{47}$ Although a C- 5 chloride substitution is more commonly reported with the Appel salt chemistry, this could present an issue relating to the ability of the chloride to act as a potential leaving group in the final compound.

The synthesis of novel 4- and 5-substituted-1,2,3dithiazoles bearing a thioketone, oxo, imino or ethyl 2-cyano-2acetate ylidene functionality at C-5 position were performed utilising the reaction between substituted ethanoneoximes and sulphur monochloride according to a one-pot protocol generating an in-situ pre-functionalised dithiazolium salt intermediate before treatment with a selected nucleophile (Scheme 1).48,37

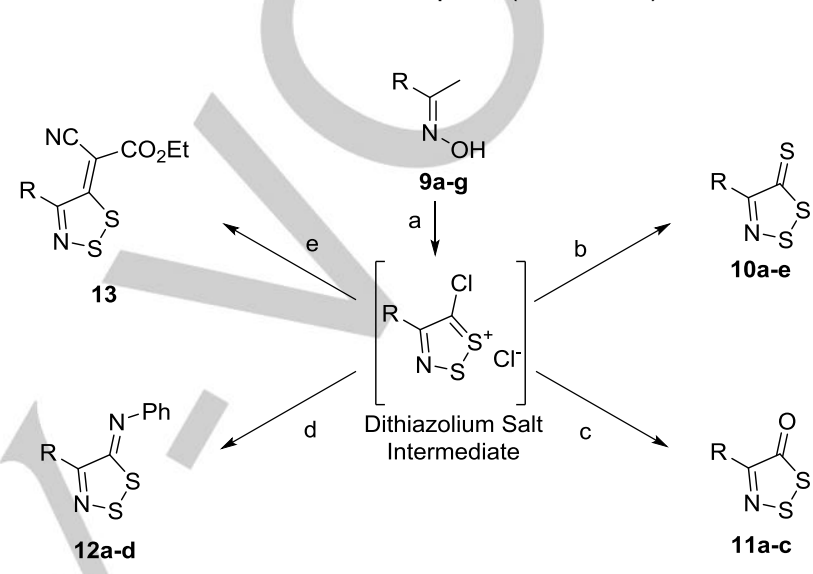

Scheme 1. Synthesis of dithiazole derivatives - Reagents and Conditions - (a) $\mathrm{S}_{2} \mathrm{Cl}_{2} /$ Pyridine, $\mathrm{CH}_{3} \mathrm{CN}$, Ar, -5 to $0{ }^{\circ} \mathrm{C}, 15$ mins; (b) thioacetamide, 0 to $25^{\circ} \mathrm{C}$, $\mathrm{CH}_{3} \mathrm{CN}, \mathrm{Ar}, 2 \mathrm{hr}$; (c) formic acid, $\mathrm{CH}_{3} \mathrm{CN}, \mathrm{Ar}, 0^{\circ} \mathrm{C}$ at 30 mins, $1 \mathrm{hr}$ at reflux; (d) ethyl 2-cyanoacetate, pyridine, $25^{\circ} \mathrm{C}, \mathrm{CH}_{2} \mathrm{Cl}_{2}, 5 \mathrm{hr}$; (e) aniline/benzyl amine, $\mathrm{CH}_{3} \mathrm{CN}, \mathrm{Ar}, 0^{\circ} \mathrm{C}$ at 30 mins, followed by pyridine.

The ethanoneoximes $9 \mathbf{a}-\mathbf{g}$ were prepared according to literature procedures in quantitative yields by heating a mixture of the corresponding ketones or aldehydes with an excess of hydroxylamine hydrochloride with sodium acetate in methanol at reflux. ${ }^{49}$ The oximes were subsequently suspended in acetonitrile and reacted with disulphur dichloride, with pyridine added dropwise to form the related dithiazolium salt intermediate, which was then treated with the appropriate nucleophilic source.

A number of methods exist for the formation of 4-chloro-1,2,3dithiazolo-5-thione, including the use of hydrogen sulphide in acetonitrile $^{46}$ or 2-cyanothioacetamide, ${ }^{50}$ but we chose to utilise thioacetamide for its ease of use and low cost. Thioacetamide was added after preparation of the dithiazole salt derivative and this selectively gave compounds $10 a-e$ in good yields. 5Oxodithiazoles were synthesised by replacing thioacetamide with formic acid, to produce 11a-c. 5-Iminodithiazoles were prepared in a similar fashion by substituting thioacetamide with aniline to give 12a-d. Compound 13 was produced by treatment of the 9a dithiazole salt derivative with ethyl cyanoacetate, although the modelling indicated that this compound was not optimal, we wanted to investigate if having a polar head group such as this cyano ester derivative would be tolerated.

Compounds $\mathbf{1 0 - 1 3}$ were then screened for toxicity in-vitro against feline kidney cells and tested for anti-viral efficacy in- vitro against a chronically infected feline lymphoid cell line. 
<smiles></smiles>

General Structure

\begin{tabular}{|c|c|c|c|c|c|c|c|}
\hline Number & $x$ & $\mathrm{R}$ & $\mathrm{CrFK}^{\mathrm{a}}$ & $\mathrm{CC}_{50}{ }^{\mathrm{b}}$ & $\mathrm{EC}_{50} \mathrm{~b}$ & $\mathrm{TI}^{\mathrm{C}}$ & $\operatorname{cLog} \mathrm{P}^{\mathrm{d}}$ \\
\hline & & & $(\%)$ & $(\mu \mathrm{M})$ & $(\mu \mathrm{M})$ & & \\
\hline $10 a$ & $S$ & Phenyl & $>100$ & $>100$ & 0.023 & $>4000$ & 3.53 \\
\hline $10 \mathrm{~b}$ & $S$ & 4-Methoxyphenyl & 96.43 & 39.24 & 0.456 & 86.1 & 3.45 \\
\hline $10 c$ & $S$ & 4-Fluorophenyl & $>100$ & 42.17 & 2.66 & 15.8 & 3.67 \\
\hline $10 d$ & $S$ & 2-Benzofuranyl & 74.1 & 3.04 & 0.9044 & 6.7 & 4.3 \\
\hline $10 \mathrm{e}$ & $S$ & 2-Thiophenyl & 57.2 & 6.02 & 0.1773 & 17.1 & 3.38 \\
\hline $11 a$ & $\mathrm{O}$ & 4-Methoxyphenyl & $>100$ & 40.84 & 0.193 & 211.6 & 2.16 \\
\hline $11 b$ & $\mathrm{O}$ & 4-Fluorophenyl & $>100$ & 63.52 & 0.025 & $>2500$ & 2.38 \\
\hline $11 \mathrm{c}$ & $\mathrm{O}$ & 4-Nitrophenyl & 87.45 & 6.26 & 0.4325 & 14.5 & 1.98 \\
\hline $12 a$ & $\mathrm{~N}-\mathrm{Ph}$ & Phenyl & 75.66 & 7.49 & 0.5888 & 12.7 & 5.84 \\
\hline $12 c$ & $\mathrm{~N}-\mathrm{Ph}$ & 4-Nitrophenyl & 92.51 & 9.74 & 0.5001 & 19.5 & 5.58 \\
\hline 12d & $\mathrm{N}-\mathrm{Ph}$ & Ethyl ester & 76.64 & 28.21 & 0.0665 & 424.2 & 4.24 \\
\hline 13 & & 4-Fluorophenyl & 90.33 & 3.24 & 0.2397 & 13.5 & 3.36 \\
\hline 14 & $S$ & Phenyl & 71.11 & 0.681 & 0.392 & 1.7 & 4.79 \\
\hline 15 & - & AZT & $>100$ & $>100$ & 5.31 & 18.8 & -0.16 \\
\hline 16 & - & raltegravir & $>100$ & $>100$ & 0.01 & $>10000$ & 1.16 \\
\hline
\end{tabular}

Table 1. Results from the 1,2,3-dithiazole scaffold FIV screening

[a] Sample concentration of $10 \mu \mathrm{M}$ of compound on CrFK cells for 24 hours percentage viability; [b] Geometric mean, each concentration tested in triplicate after 7 days as a difference of a untreated DMSO control FL-4 cells with a less than $10 \%$ error; [c] Therapeutic index is $\mathrm{CC}_{50} / \mathrm{EC}_{50}$, which is the ratio of toxicity to activity; [d] Calculated using ChemBioDraw Ultra 14.

Biological testing of the compounds was based on dual approach, the first aimed to identify any compounds with nonspecific toxicity at three higher concentrations $(1 \mu \mathrm{M}-100 \mu \mathrm{M})$ in a short MMT cell viability assay ${ }^{51}$ over 24 hours exposing Crandell Rees Feline Kidney cells (CrFK). ${ }^{52}$ The second provided an enhanced longer-term cytotoxicity screen and an anti-FIV profile at six concentrations ( $1 \mathrm{nM}$ to $100 \mu \mathrm{M}$ ) over seven days, using an IL-2 independent feline lymphoblastoid cell line (FL-4). ${ }^{53}$ FL-4 cells infected with FIV were exposed to the compounds over a period of seven days and sampled every day and at each of six concentrations; to determine the extent of viral replication/suppression. Viral RNA was isolated from cell culture supernatants using the MagNA Pure LC System by the Total Nucleic Acid Isolation Kit (Roche Applied Science). Viral loads were determined by quantitative real-time reverse transcription polymerase chain reaction (RT-qPCR) ${ }^{54}$ The remaining cells were subjected to a MTT cell viability assay to rule out any toxicity effects and validate that the RT- GPCR result is not caused by non-specific toxicity and provide a therapeutic index for each compound.

The results obtained demonstrated that activity was observed at varying potencies across each series with nanomolar activities as seen with $\mathbf{1 0 a}$ (Table 1 ). Toxicity was generally light when observed in the initial screening with CrFK cells with 24hours exposure. This is generally a good indication of the level of toxicity that would be observed if there was a clearance mechanism in the FL-4 assay. There appears to be a roughly tenfold increase in toxicity when looking at the results for the FL-4 assay relative to the CrFK data, but this has to be taken in the context of chronic exposure in an in-vitro assay and would not necessarily be truly representative of an in-vivo system. Importantly, the overall results show that even with prolonged exposure to these potentially zinc abstracting agents there is a good therapeutic index, which suggests that zinc abstraction is not intrinsically tied to cytotoxicity. The toxicity does not show any correlation with the activity displayed by the most active compounds such as $10 \mathrm{a}$ and $\mathbf{1 1} \mathrm{b}$. While 12a also displays good activity and represents an improvement on previous work within our group, the therapeutic index $\left(\mathrm{CC}_{50} / \mathrm{EC}_{50}\right)$ still requires further improvement.

After the initial promising result with 10 a we looked to expand a small cluster of compounds around the main scaffold and alter structural features of the core compound to increase the 
therapeutic index. However, with $\mathbf{1 0 b}-\mathbf{e}$, we found there to be a drop off in activity when compared to $10 \mathrm{a}$, with $10 \mathrm{~d}$ and $10 \mathrm{e}$ showing unfavorable therapeutic indexes when compared to $10 a$, combined with lower overall activity. The slightly increased $\mathrm{EC}_{50}$ of $10 \mathrm{c}$ could be due to limited cell penetration compared to the other counterparts or the fact that sulphur is less electronegative relative to oxygen..$^{55}$ This drop in activity was not observed with the switch to the oxygen analogue 11b which was almost as potent as $10 \mathbf{a}$, but in displaying increased toxicity, the corresponding therapeutic index was lower. We expected a boost from a nitro group substitution (11c and 12c) but this modification led to an increase in toxicity with no material potency gain. The consistent substituent across each series was the paramethoxyphenyl group, which was used to screen the 'head group'. Whilst the results of these compounds were quite consistent, they did not demonstrate improved potency but displayed increased toxicity when compared with $\mathbf{1 0 a}$ in this in-vitro system. Interestingly an increase in cLogP beyond 5 did not significantly inhibit the activity or affect the solubility of compounds 12a-c. 12d and $\mathbf{1 3}$ were investigated to understand if disruption to the core structure via removal of sulphur or oxygen would be tolerated and whilst activity was observed, there was not a significant improvement over $\mathbf{1 0 a}$, due to an increased metabolic liability from the ethyl ester. The activity of azidothymidine (AZT) - 15 and raltegravir - $\mathbf{1 6}$ are consistent with previous reports in FIV/HIV. ${ }^{56,57}$

The focus of this work builds on the idea that the disulphide bridge is pivotal to the activity of the compounds against the NCp target, we also aimed to demonstrate that the disulphide is essential for activity by synthesizing a disrupted 1,2,3-dithiazole system with a disulphide bond by treatment of $10 \mathrm{a}$ with benzylamine (Scheme 2), ${ }^{58,59}$ to give 1,2,5-thiadiazolothione 14. However, we found the utility of this compound to be limited by toxicity, after prolonged cellular exposure. The $E_{50}$ closely mapped to the $\mathrm{CC}_{50}$ with a resulting therapeutic index of less than 2 , this meant that this was not a definitive way to demonstrate if the disulphide bridge was essential or not. This observation may/may not support our hypothesis that the disulphide bridge was essential for the activity observed, but was not conclusive.

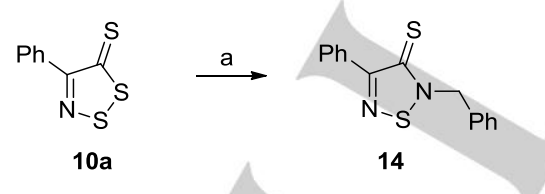

Scheme 2. Reaction of 5H-1,2,3-dithiazole-5-thiones 10a to form 14 - Reagents and Conditions - (a) benzyl amine, THF, Ar, 3 hr, r.t.

With the activities observed our proposed mechanism of action of this class of compound involves modification of the zincbinding sites on the NCp of FIV which we determined using DFT calculations. Support for this idea comes from previous NMR and MS studies on HIV NCp7 that have shown observable formation of protein-zinc-thiol(ate) complexes and covalent modifcations. ${ }^{25}$ We reasoned that 1,2,3-dithiazole mediated zinc ion abstraction ejection also occurs via an analogous mechanism to known zinc binding/disrupting compounds in which a zinc-binding cysteinyl thiol(ate) reacts with the disulphide of the core to generate a transient protein-DTA disulphide (Figure 3)..$^{25,36,60}$ This can then rearrange to form an intramolecular protein disulphide with consequent reduction in zinc ion affinity. The ejected zinc ion (or zinc 1,2,3-dithiazole complex) could then potentially complex with a second (reduced) 1,2,3-dithiazole core to form a stable complex which is analogous to work previously reported on the epidithiodiketopiperazine class of natural products. ${ }^{60-62}$

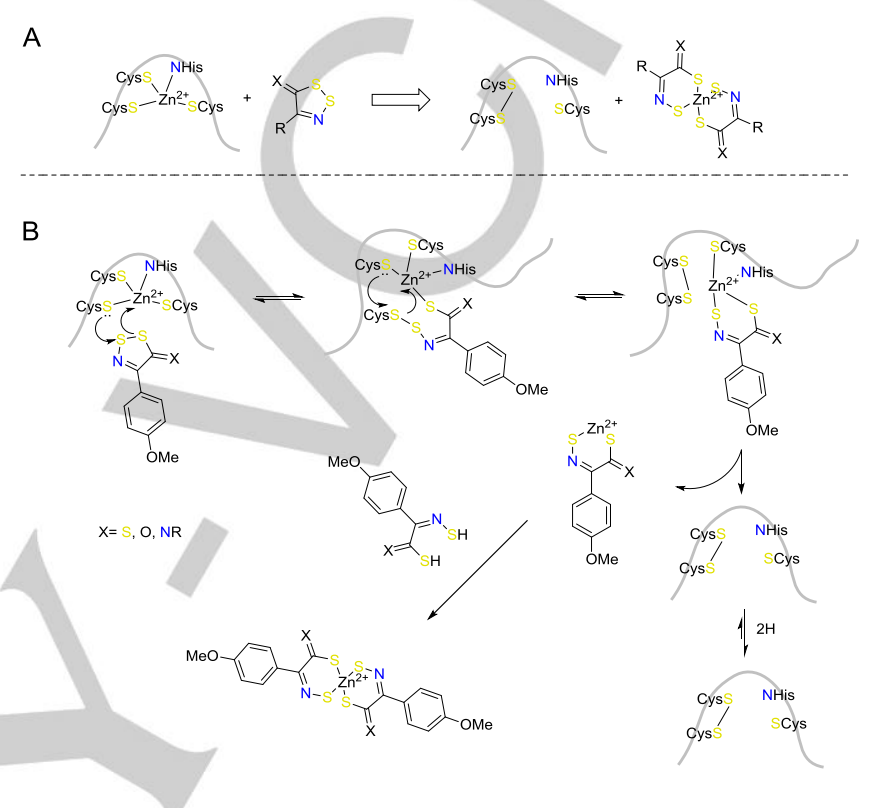

Figure 3. Proposed mechanism of action of 1,2,3-dithiazole for modification of NCp homology model. $\boldsymbol{A}$ - summary of the mechanism of zinc ejection from $\mathrm{NCp} / \mathrm{NCp} 7$. $\boldsymbol{B}$ - a $\mathrm{Zn}^{2+-}$ coordinating cysteine thiol(ate) reacts with the disulphide of the 1,2,3-dithiazole core to generate a transient intermediate disulphide. The disulphide then rearranges to form an intramolecular protein disulphide with consequent reduction in zinc ion affinity. The ejected zinc ion (or part $\mathrm{Zn}^{2+}$ complex) can then complex with a second 1,2,3-dithiazole core (reduced) to form a stable complex.

Observations from our calculations show that it is unlikely that thermodynamic parameters drive the observed kinetics. Once disulphide exchange occurs between the zinc finger and the inhibitor, the zinc finger in the protein is no longer able to re-form and equilibrium to regenerate the structure is unable to be established. We therefore propose this mechanism using a kinetic argument whereby the energy barrier for zinc ejection is favored and in addition that the formation of a stable zinc complex is potentially thermodynamically favored. When the requisite disulphide bridge in the inhibitor is interrupted in compound $\mathbf{1 4}$, this disruption to the zinc finger can no longer occur and abstraction of zinc by our proposed mechanism is not available to this compound leading to the observed limited activity (Figure 4). 


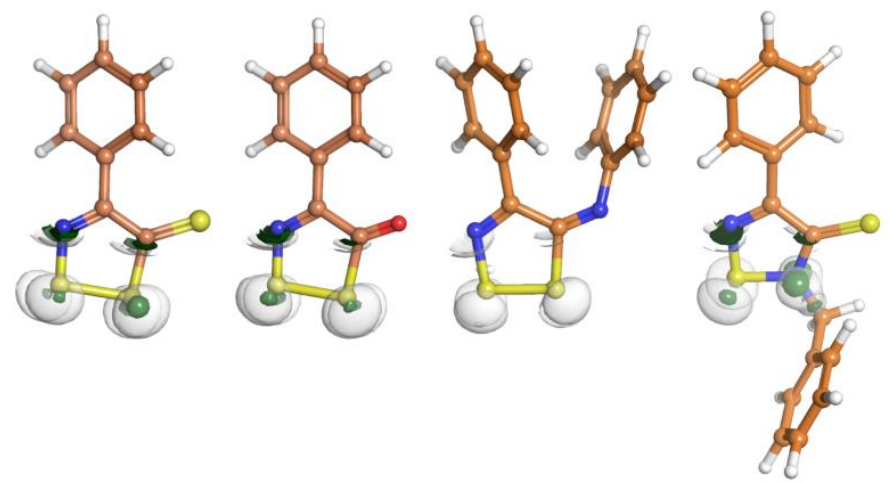

Figure 4. Global reactivity was estimated by calculation of the Fukui frontier molecular orbitals of $\mathbf{1 0 - 1 4}$ respectively and the propensity of the protein to undergo zinc abstraction. Fukui $f+$ negative visualized using iso-values 0.0015 (white) and 0.005 (green), (Schrödinger Maestro).

\section{Conclusions}

The sub-micromolar potencies of the compounds described in this study combined with the lower toxicities show a step change in progression towards the development of useful candidate compound for the targeting of the FIV/HIV nucleocapsid protein. The low toxicity and high activity of the initial hit 10a led us to believe that improved compounds with enhanced characteristics were possible. Many avenues of development exist such as a substitution at the para position of the pendant phenyl ring to prevent P450 metabolism while still maintaining activity. We demonstrated that 10 a struck a good overall balance between activity and toxicity. With the quantum calculations demonstrating the viability of zinc ejection, this opens up the possibility of our investigations with the aim of generating lead structures with more favorable profiles. While we have enhanced the repertoire of the 5-thieno, 5-oxo, 5-imino-1,2,3-dithiazole class of compounds, the hope is that this work will allow us to generate a pre-clinical candidate that can treat both FIV and HIV in an in-vivo setting and this will be reported in due course.

\section{Experimental Section}

\section{Modelling Calculations}

\section{Molecular Docking}

A quantum polarized molecular docking study for a number of compounds (Figure 2) was conducted, which was similar to that previously generated using a homology model, ${ }^{31}$ with the version used in this study based on HIV-1 PDB:2JZW (NCp7) ${ }^{63}$ and EIAV PDB:2BL6 (NCp11) as a model for the FIV NCp. ${ }^{16}$ The inhibitory mechanism of compounds is assumed to begin with coordination of compounds against more the accessible zinc finger motif of the model (Figure 3). Our previous homology modelling and docking studies suggest that inhibitory activity can be partly explained by means of facile coordination of compounds close to the more accessible zinc finger structure.

\section{DFT Molecular Orbital Calculations.}

The zinc finger structure is not well described by means of molecular mechanics based molecular docking; hence we used Jaguar DFT calculations for docking pose derived model. The geometry of zinc finger cysteines and histidines were constrained to their initial geometry using Cartesian constraints to connector carbon atoms. B3LYP of theory and MSV basis set were used for geometry optimizations in the gas phase. Reactivity of selected compounds were separately estimated by unconstrained gas phase geometry optimizations (B3LYP/6-31 $\mathrm{g}^{\star *}$ ) followed by single point Fukui frontier molecular orbital calculations (visualised in Figure 4), (Schrödinger Inc., New York, NY, USA).

\section{Biology}

\section{Initial Short Cytotoxicity Assay.}

Crandell Reese feline kidney (CrFK) cells ${ }^{52}$ were cultured in 96well plates (TPP, Trasadingen, Switzerland) at a density of 10,000 cells/well, in complete medium (RPMI 1640 medium (SigmaAldrich, Buchs, Switzerland), containing 10\% Fetal Calf Serum (FCS) $100 \mathrm{M} / \mathrm{mL}$ Glutamine and 1\% v/v antibiotic/antimycotic (Ab/Am) (all three, Gibco Life Technologies, Zug, Switzerland)). The antiviral compounds were dissolved in $2 \%$ DMSO (SigmaAldrich, Buchs, Switzerland) to make a $1 \mathrm{M}$ stock solution. The compounds were 10 -fold serially diluted with complete medium. Six dilutions of the compounds ( $100 \mu \mathrm{M}$ to $1 \mathrm{nM}$ ) were added in triplicate on the CrFK cells $(200 \mu \mathrm{L})$ and incubated for 24 hours $\left(37^{\circ} \mathrm{C}, 5 \% \mathrm{CO}_{2}\right)$. The medium was removed and replaced with phenol red free medium and (180 $\mu \mathrm{L})$ and methylthiazolyldiphenyl-tetrazolium bromide (MTT) $(4 \mathrm{mg} / \mathrm{mL}$ ) (Sigma-Aldrich, Buchs, Switzerland) $(20 \mu \mathrm{L})$ incubated for 4 hours. The medium was removed by vacuum and the cells were lysed with methanol $(200 \mu \mathrm{L})$ to reveal a bright purple formazan product. ${ }^{51}$ The methanol-formazan absorbance was determined at $570 \mathrm{~nm}$ (BioTek Synergy HT plate reader with KC4 software, Cambridge systems) values expressed as a $50 \%$ cytotoxic concentration $\left(\mathrm{CC}_{50}\right)$.

\section{FIV Viral Loading Studies.}

The potential antiviral effect against FIV was tested in a cell culture assay using an IL-2 independent feline FL-4 feline lymphoblastoid cell line. ${ }^{53}$ The compounds were added as concentrations ranges in triplicate as above. The cell supernatant $(100 \mu \mathrm{L})$ was removed, frozen at $-20^{\circ} \mathrm{C}$ and replaced daily for 7 days. To determine the "long-term" cytotoxicity, on Day 7 the cell culture supernatant was replaced with phenol red free medium $(80 \mu \mathrm{L})$ and the cells were subjected to the MTT assay (as before). The day 7 cell culture supernatants were centrifuged in a tabletop centrifuge $(10000 \times \mathrm{g})$ maximal speed for 2 min to pellet cells and debris. Cell culture supernatant of each triplicate were pooled and frozen immediately at $-20^{\circ} \mathrm{C}$ until analysis. Total nucleic acids (TNA) were extracted using the MagnaPure LC TNA extraction kit (Roche, Basel, Switzerland) from $100 \mu \mathrm{L}$ of pooled according to manufacturer's instructions. FIV RNA was quantitated by RT- 
qPCR as described for FIV, using DSMO and untreated cells as controls. ${ }^{54}$ Results were expressed as 50\% effective concentrations $\left(E_{50}\right)$ determined by a sigmoid dose-response curve at $50 \%$ inhibition determined by sigmoid dose-response curve fitting using GraphPad Prism version 6.0 (GraphPad Inc., La Jolla, CA, USA) and an RNA standard.

\section{Chemistry}

General - Melting points were determined on a Kofler hot-stage apparatus and are uncorrected. IR spectra were recorded on a Specord $\mathrm{M}-80$ instrument in $\mathrm{KBr}$ pellets. ${ }^{1} \mathrm{H}$ NMR were recorded on a Bruker WM 300 spectrometer $(300 \mathrm{MHz})$ and ${ }^{13} \mathrm{C}$ NMR spectra were recorded on a Bruker AM $300(75.5 \mathrm{MHz})$ in $\mathrm{CDCl}_{3}$. $J$ values are given in hertz. Mass spectra were recorded on a Finnigan MAT INCOS 50 instrument using electron impact ionization. Elemental analyses were performed on Perkin Elmer 2400 Elemental Analyser.

General Procedure A: 4-Phenyl-5H-1,2,3-dithiazole-5-thione (10a): Pyridine $(0.243 \mathrm{~mL}, 3.0 \mathrm{mmol})$ was added dropwise at -5 to $0{ }^{\circ} \mathrm{C}$ to a stirred solution of $(E)$-1-phenylethan-1-one oxime $9 \mathrm{a}^{47}$ $(135 \mathrm{mg}, 1.0 \mathrm{mmol})$ and sulphur monochloride $(0.160 \mathrm{~mL}$, $2.0 \mathrm{mmol})$ in acetonitrile $(10 \mathrm{~mL})$ under an inert atmosphere of argon. The mixture was stirred at $0{ }^{\circ} \mathrm{C}$ for $15 \mathrm{~min}$ and thioacetamide ( $83 \mathrm{mg}, 1.1 \mathrm{mmol}$ ) added in one portion and the resulting mixture stirred at r.t. for $2 \mathrm{~h}$, filtered and solvents evaporated under reduced pressure. The residue was purified by column chromatography (Silica gel Merck 60, light petroleum and then light petroleum- $\mathrm{CH}_{2} \mathrm{Cl}_{2}$ mixtures) to afford compound $10 \mathrm{a}$ as a brown solid (155 mg, 73\%): m.p. $95-100{ }^{\circ} \mathrm{C}$. Anal. Calcd for $\mathrm{C}_{8} \mathrm{H}_{5} \mathrm{NS}_{3}(\%): \mathrm{C}, 45.47 ; \mathrm{H}, 2.39 ; \mathrm{N}, 6.63$. Found (\%): C, 45.55; $\mathrm{H}$, 2.43; N, 6.70. ${ }^{1} \mathrm{H}$ NMR (300 MHz, $\left.\mathrm{CDCl}_{3}\right) \delta: 7.36(3 \mathrm{H}, \mathrm{m}, \mathrm{Ph}), 7.47$ $(2 \mathrm{H}, \mathrm{m}, \mathrm{Ph}) .{ }^{13} \mathrm{C}$ NMR $\left(75.5 \mathrm{MHz}, \mathrm{CDCl}_{3}\right) \delta: 128.0,(2 \mathrm{CH}, \mathrm{Ph})$, $129.4(2 \mathrm{CH}, \mathrm{Ph}), 130.5(\mathrm{CH}, \mathrm{Ph}), 131.3,179.3\left(2 \mathrm{sp}^{2}\right.$ tertiary $\left.\mathrm{C}\right)$, 208.0 (C=S). MS (El, $70 \mathrm{eV}), \mathrm{m} / \mathrm{z}(\%): 211\left(\mathrm{M}^{+}, 100\right), 135$ (95), 103 (30). IR (KBr), v/cm ${ }^{-1}$ : 3056, $2920(\mathrm{C}-\mathrm{H}), 2852,2356,2336$, 1436, $1132(\mathrm{C}=\mathrm{S}), 604,499(\mathrm{~S}-\mathrm{S}) .{ }^{37}$

4-(4-Methoxyphenyl)-5H-1,2,3-dithiazole-5-thione (10b): $(E)$ 1-(4-Methoxyphenyl)ethan-1-one oxime $9 b^{47}$ (165 mg, $\left.1 \mathrm{mmol}\right)$ was treated according to general procedure $A$ to afford compound $10 \mathrm{~b}$ as pale brown crystals $(73 \mathrm{mg}, 30 \%)$ : m.p. $68-71^{\circ} \mathrm{C}$. Anal. Calcd. for $\mathrm{C}_{9} \mathrm{H}_{7} \mathrm{NOS}_{3}(\%): \mathrm{C}, 44.79 ; \mathrm{H}, 2.92 ; \mathrm{N}, 5.80 ; \mathrm{O}, 6.63$. Found (\%): C, 44.95; $\mathrm{H}, 3.08 ; \mathrm{N}, 6.04 .{ }^{1} \mathrm{H} \mathrm{NMR}\left(300 \mathrm{MHz}, \mathrm{CDCl}_{3}\right)$, $\delta: 3.87\left(3 \mathrm{H}, \mathrm{s}, \mathrm{CH}_{3}\right) ; 6.98(2 \mathrm{H}, \mathrm{d}, 2 \mathrm{CH}, J=8.8 \mathrm{~Hz}), 8.98(2 \mathrm{H}, \mathrm{d}$, $2 \mathrm{CH}, J=8.8 \mathrm{~Hz}) .{ }^{13} \mathrm{C} \mathrm{NMR}\left(75.5 \mathrm{MHz}, \mathrm{CDCl}_{3}\right) \delta: 55.4\left(\mathrm{CH}_{3}\right)$, 113.5 (2 CH, Ar), 123.9 (2 CH, Ar), 131.1, 161.4, 167.3 (3 $\mathrm{C}_{\text {quat }}$ ), $208.4(\mathrm{C}=\mathrm{S})$. MS (El, $70 \mathrm{eV}), \mathrm{m} / \mathrm{z}(\%): 241\left(\mathrm{M}^{+}, 28\right), 210$ (15), 197 (4), 133 (100). IR (KBr), v/cm ${ }^{-1}: 2924(\mathrm{C}-\mathrm{H}), 2852,1600,1516$, $1280,1144,1036,828,752,700 .{ }^{48}$

4-(4-Fluorophenyl)-5H-1,2,3-dithiazole-5-thione (10c): (E)-1(4-Fluorophenyl)ethan-1-one oxime $9 \mathrm{c}^{47}(153 \mathrm{mg}, 1 \mathrm{mmol})$ was treated according to general procedure $A$ to afford compound $10 \mathrm{c}$ as brown crystals $(92 \mathrm{mg}, 40 \%)$ : m.p. $148-152^{\circ} \mathrm{C}$. Anal. Calcd for $\mathrm{C}_{8} \mathrm{H}_{4} \mathrm{FNS}_{3}(\%)$ : C, 41.90; H, 1.76; N, 6.11. Found (\%): C, 41.83; $\mathrm{H}, 1.89$; F, 8.29; N, 6.11. ${ }^{1} \mathrm{H}$ NMR $\left(300 \mathrm{MHz}, \mathrm{CDCl}_{3}\right) \delta: 7.15(2 \mathrm{H}$ $\mathrm{t}, J=8.80, \mathrm{Ar}), 7,98(2 \mathrm{H}, \mathrm{m}, \mathrm{Ar}) \cdot{ }^{13} \mathrm{C} \mathrm{NMR}\left(75.5 \mathrm{MHz}, \mathrm{CDCl}_{3}\right) \delta$ :

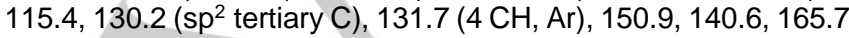
(3 $\mathrm{sp}^{2}$ tertiary C), $208.0(\mathrm{C}=\mathrm{S})$. MS (El, $\left.70 \mathrm{eV}\right), \mathrm{m} / \mathrm{z}(\%): 229\left(\mathrm{M}^{+}\right.$, 78), 209 (10), 185(12), 153 (89). IR (KBr), v/cm-1: $2924(\mathrm{C}-\mathrm{H})$, $2856,1888,1600,1508,1408,1272,1136,852,792,680 .^{37}$
4-(1-Benzofuran-2-yl)-5H-1,2,3-dithiazole-5-thione (10d): $(E)$ 1-(Benzofuran-2-yl)ethan-1-one oxime $9 \mathbf{d}^{47}$ (175 mg, $\left.1 \mathrm{mmol}\right)$ was treated according to general procedure $A$ to afford compound $10 \mathrm{~d}$ as red crystals $(138 \mathrm{mg}, 55 \%)$ : m.p. $132-134^{\circ} \mathrm{C}$. Anal. Calcd for $\mathrm{C}_{10} \mathrm{H}_{5} \mathrm{NOS}_{3}(\%)$ : C 47.79; $\mathrm{H}, 2.01 ; \mathrm{N}, 5.57 ; \mathrm{O}, 6.37$. Found (\%): $\mathrm{C}, 47.92 ; \mathrm{H}, 2.23 ; \mathrm{N}, 6.76 .{ }^{1} \mathrm{H}$ NMR $\left(300 \mathrm{MHz}, \mathrm{CDCl}_{3}\right)$ ס: $7.32(1 \mathrm{H}$, $\mathrm{m}, \mathrm{Bzf}), 7.44(1 \mathrm{H}, \mathrm{m}, \mathrm{Bzf}), 7.62(1 \mathrm{H}, \mathrm{d}, J=8.1, \mathrm{Bzf}), 7.73(1 \mathrm{H}, \mathrm{d}$, $J=7.3, \mathrm{Bzf}), 8.50(1 \mathrm{H}, \mathrm{s}, \mathrm{Bzf}) .{ }^{13} \mathrm{C}$ NMR $\left(75.5 \mathrm{MHz}, \mathrm{CDCl}_{3}\right) \delta$ : 110.7, 111.4, 122.9, 123.6, 127.1 (5 CH, Bzf), 132.9, 140.8, 147.6, 168.7 (4 sp $\mathrm{sp}^{2}$ tertiary C), $205.2(\mathrm{C}=\mathrm{S})$. MS (EI, $\left.70 \mathrm{eV}\right), \mathrm{m} / \mathrm{z}(\%): 251$ $\left(\mathrm{M}^{+}, 23\right), 175(59), 143(58)$. IR (KBr), v/cm ${ }^{-1}: 1648,1612,1560$, $1348,1260,1164,1036,828,748,700 .^{37}$

4-Thien-2-yl-5H-1,2,3-dithiazole-5-thione (10e): $\quad(E)-1-$ (Thiophen-2-yl)ethan-1-one oxime $9 \mathrm{e}^{63}(141 \mathrm{mg}, 1 \mathrm{mmol})$ was treated according to general procedure $A$ to afford compound $10 \mathrm{e}$ as red crystals (54 mg, 25\%): m.p. $89-92{ }^{\circ} \mathrm{C}$. Anal. Calcd for $\mathrm{C}_{6} \mathrm{H}_{3} \mathrm{NS}_{4}(\%) . \mathrm{C}, 33.16 ; \mathrm{H}, 1.39 ; \mathrm{N}, 6.44$. Found (\%): C, 33.28; $\mathrm{H}$, 1.54; N, 6.14. HRMS Anal. Calcd for $\mathrm{C}_{6} \mathrm{H}_{3} \mathrm{NS}_{4}: 216.9148$, Found: 216.9151. ${ }^{1} \mathrm{H}$ NMR $\left(300 \mathrm{MHz}, \mathrm{CDCl}_{3}\right) \delta: 7.14(1 \mathrm{H}, \mathrm{m}, \mathrm{Th}), 7.53$ $(1 \mathrm{H}, \mathrm{d}, J=5.1 \mathrm{~Hz}, \mathrm{Th}), 8.36(1 \mathrm{H}, \mathrm{d}, J=4.4 \mathrm{~Hz}, \mathrm{Th}) .{ }^{13} \mathrm{C}$ NMR $\left(75.5 \mathrm{MHz}, \mathrm{CDCl}_{3}\right)$ d: 127.2, 130.7, 131.7 (3 CH, Th), 133.9, 164.0 (2 sp $\mathrm{sp}^{2}$ tertiary C), $205.6(\mathrm{C}=\mathrm{S})$. MS (El, $\left.70 \mathrm{eV}\right), \mathrm{m} / \mathrm{z}(\%): 217\left(\mathrm{M}^{+}\right.$, 73), 141 (100), 109 (53). IR (KBr), v/cm ${ }^{-1}: 3100,2920(\mathrm{C}-\mathrm{H}), 2852$, $1520,1412,1364,1276,1140,984,824,784 .^{37}$

General Procedure B: 4-(4-Methoxyphenyl)-5H-1,2,3dithiazole-5-one (11a): Pyridine $(0.243 \mathrm{~mL}, 3 \mathrm{mmol})$ was added dropwise at -5 to $0{ }^{\circ} \mathrm{C}$ to a stirred solution of $(E)-1-(4-$ methoxyphenyl)ethan-1-one oxime $9 \mathrm{f}^{47}$ (165 mg, $1 \mathrm{mmol}$ ) and sulphur monochloride $(0.160 \mathrm{~mL}, 2 \mathrm{mmol})$ in acetonitrile $(10 \mathrm{~mL})$ under argon. The mixture was stirred at $0{ }^{\circ} \mathrm{C}$ for $15 \mathrm{~min}$ followed by addition of formic acid $(0.189 \mathrm{~mL}, 5 \mathrm{mmol})$ and the resulting mixture was stirred at $0{ }^{\circ} \mathrm{C}$ for $30 \mathrm{~min}$ and heated at reflux for $1 \mathrm{~h}$, filtered and solvent were evaporated under reduced pressure. The residue was purified by column chromatography (Silica gel Merck 60, light petroleum and then light petroleum- $-\mathrm{CH}_{2} \mathrm{Cl}_{2}$ mixtures) to afford compound 11a as yellow crystals (146 mg, $65 \%$ ): m.p. $59-62^{\circ} \mathrm{C}$. Anal. Calcd. for $\mathrm{C}_{9} \mathrm{H}_{7} \mathrm{NO}_{2} \mathrm{~S}_{2}(\%): \mathrm{C}, 47.98 ; \mathrm{H}$, 3.13; N, 6.22; O, 14.20. Found (\%): C, 48.12; H, 3.31; N, 6.48. ${ }^{1} \mathrm{H}$ NMR $\left(300 \mathrm{MHz}, \mathrm{CDCl}_{3}\right) \delta: 3.87\left(3 \mathrm{H}, \mathrm{s}, \mathrm{CH}_{3}\right) 6.97(2 \mathrm{H}, \mathrm{d}, J=8.8$ $\mathrm{Hz}, \mathrm{Ar}), 8.15(2 \mathrm{H}, \mathrm{d}, J=9.5 \mathrm{~Hz}, \mathrm{Ar}) .{ }^{13} \mathrm{C} \mathrm{NMR}\left(75.5 \mathrm{MHz}, \mathrm{CDCl}_{3}\right)$ ठ: $55.5\left(\mathrm{CH}_{3}\right), 114.1(2 \mathrm{CH}, \mathrm{Ar}), 129.6(2 \mathrm{CH}, \mathrm{Ar}), 123.8,154.4$, $161.8\left(3 \mathrm{sp}^{2} \mathrm{C}\right), 190.5(\mathrm{C}=\mathrm{O})$. MS (El, $\left.70 \mathrm{eV}\right), \mathrm{m} / \mathrm{z}(\%): 225\left(\mathrm{M}^{+}\right.$, 27), 197 (7), 165 (5), 133 (100). IR (KBr), v/cm ${ }^{-1}: 3064(\mathrm{C}-\mathrm{H}), 3008$, 2920, 2840, 1656 (C=O), 1576, 1508, 1248, 1180, 832, 684. . $^{59}$

4-(4-Fluorophenyl)-5H-1,2,3-dithiazole-5-one (11b): (E)-1-(4Fluorophenyl)ethan-1-one oxime $9 \mathrm{c}^{47}(153 \mathrm{mg}, 1 \mathrm{mmol})$ was treated according to general procedure $B$ to afford compound $\mathbf{1 1 b}$ as yellow crystals $(107 \mathrm{mg}, 50 \%)$ : m.p. $70-72^{\circ} \mathrm{C}$. Anal. Calcd. for $\mathrm{C}_{8} \mathrm{H}_{4} \mathrm{FNOS}_{2}$ (\%): C, 45.06; H, 1.89; F, 8.91; N, 6.57; O, 7.50. Found (\%): C, 44.89; $\mathrm{H}, 1.98 ; \mathrm{N}, 6.37 .{ }^{1} \mathrm{H}$ NMR (300 MHz, $\left.\mathrm{CDCl}_{3}\right)$ $\delta: 7.15(2 \mathrm{H}, \mathrm{t}, J=8.5, \mathrm{Ar}), 8.19(2 \mathrm{H}, \mathrm{t}, J=8.5, \mathrm{Ar}) .{ }^{13} \mathrm{C}$ NMR $(75.5$ $\left.\mathrm{MHz}, \mathrm{CDCl}_{3}\right) \delta: 115.8(2 \mathrm{CH}, \mathrm{d}, J=23.0 \mathrm{~Hz}, \mathrm{Ar}), 130.1(2 \mathrm{CH}, \mathrm{d}$, $J=7.0 \mathrm{~Hz}, \mathrm{Ar}), 127.1,153.8,164.3(\mathrm{C}-\mathrm{F}, \mathrm{s}, J=251.0 \mathrm{~Hz}),\left(3 \mathrm{sp}^{2}\right.$ C), 190.1 (C=O). MS (El, $70 \mathrm{eV}), \mathrm{m} / \mathrm{z}(\%): 213\left(\mathrm{M}^{+}, 14\right), 185(14)$, 121 (40). IR (KBr), v/cm ${ }^{-1}: 3072(\mathrm{C}-\mathrm{H}), 1920,1676(\mathrm{C}=\mathrm{O}), 1596$, $1512,1408,1272,1164,804,696 .^{59}$

4-(4-Nitrophenyl)-5H-1,2,3-dithiazole-5-one (11c): (E)-1-(4Nitrophenyl)ethan-1-one oxime $9 \mathrm{f}^{47}(153 \mathrm{mg}, 1 \mathrm{mmol})$ was treated according to general procedure $B$ to afford compound $10 \mathrm{c}$ as yellow crystals $(84 \mathrm{mg}, 35 \%)$ : m.p. $155-156^{\circ} \mathrm{C}$. Anal. Calcd. for $\mathrm{C}_{8} \mathrm{H}_{4} \mathrm{~N}_{2} \mathrm{O}_{3} \mathrm{~S}_{2}$ (\%): C, 39.99; $\mathrm{H}, 1.68 ; \mathrm{N}, 11.66$. Found (\%): C, 
40.31; H, 1.81; N, 11.62; O, 19.98; S, 26.69. ${ }^{1} \mathrm{H}$ NMR $(300 \mathrm{MHz}$, $\left.\mathrm{CDCl}_{3}\right) \delta: 8.33(2 \mathrm{H}, \mathrm{d}, J=8.8 \mathrm{~Hz}, \mathrm{Ar}), 8.40(2 \mathrm{H}, \mathrm{d}, J=8.8 \mathrm{~Hz}, \mathrm{Ar})$. ${ }^{13} \mathrm{C}$ NMR $\left(75.5 \mathrm{MHz}, \mathrm{CDCl}_{3}\right) \delta: 129.0(2 \mathrm{CH}, \mathrm{Ar}), 133.9(2 \mathrm{CH}, \mathrm{Ar})$, 141.7, 153.4, $158.7\left(3 \mathrm{sp}^{2} \mathrm{C}\right), 195.5(\mathrm{C}=\mathrm{O})$. MS (El, $\left.70 \mathrm{eV}\right), \mathrm{m} / \mathrm{z}$ $(\%): 240\left(\mathrm{M}^{+}, 5\right)$. IR (KBr), v/cm ${ }^{-1}: 3100(\mathrm{C}-\mathrm{H}), 1667(\mathrm{C}=\mathrm{O}), 1652$, $1600,1512,1408,1348,1300,1272,860,796,672.59$

General Procedure C: $\mathrm{N}$-[(5Z)-4-Phenyl-5H-1,2,3-dithiazol-5ylidene]aniline (12a): Pyridine $(0.243 \mathrm{~mL}, 3 \mathrm{mmol})$ was added dropwise at -5 to $0{ }^{\circ} \mathrm{C}$ to a stirred solution of $(E)$-1-phenylethan1-one oxime $9 \mathbf{a}^{47}(135 \mathrm{mg}, 1 \mathrm{mmol})$ and sulphur monochloride $(0.160 \mathrm{~mL}, 2 \mathrm{mmol})$ in acetonitrile $(10 \mathrm{~mL})$ under an inert atmosphere of argon. The mixture was stirred at $0{ }^{\circ} \mathrm{C}$ for $15 \mathrm{~min}$, whereupon aniline $(1 \mathrm{mmol})$ was added and the mixture stirred at $0{ }^{\circ} \mathrm{C}$ for $30 \mathrm{~min}$, followed by addition of pyridine $(0.162 \mathrm{~mL}, 2$ $\mathrm{mmol})$. The reaction mixture was filtered and solvents were evaporated under reduced pressure. The residue was purified by column chromatography (Silica gel Merck 60, light petroleum and then light petroleum- $\mathrm{CH}_{2} \mathrm{Cl}_{2}$ mixtures) to afford compound 12a as bright yellow crystals ( $149 \mathrm{mg}, 55 \%$ ): m.p. $73-76{ }^{\circ} \mathrm{C}$. Anal. Calcd. for $\mathrm{C}_{14} \mathrm{H}_{10} \mathrm{~N}_{2} \mathrm{~S}_{2}(\%)$ : C, 62.19; H, 3.73; N, 10.36. Found (\%): C, 62.25; H, 3.68; N, 10.62. ${ }^{1} \mathrm{H}$ NMR $\left(300 \mathrm{MHz}, \mathrm{CDCl}_{3}\right) \delta: 7.19(3 \mathrm{H}$, $\mathrm{m}, \mathrm{Ph}), 7.48(5 \mathrm{H}, \mathrm{m}, \mathrm{Ph}), 8.22(2 \mathrm{H}, \mathrm{m}, \mathrm{Ph}) .{ }^{13} \mathrm{C} \mathrm{NMR}(75.5 \mathrm{MHz}$, $\left.\mathrm{CDCl}_{3}\right)$ ठ: 119.0, 125.6, 128.1, 129.0, 129.8, $130.3(10 \mathrm{CH}, \mathrm{Ar})$, 132.6, 153.1, 159.2, 165.4 (4 sp $\mathrm{sp}^{2}$ tertiary C). MS (El, $\left.70 \mathrm{eV}\right), \mathrm{m} / \mathrm{z}$ (\%): $270\left(\mathrm{M}^{+}, 96\right) . \mathrm{IR}(\mathrm{KBr}), \mathrm{v} / \mathrm{cm}^{-1}: 3048(\mathrm{C}-\mathrm{H}), 1604,1598,1500$ $(\mathrm{C}=\mathrm{N}), 1280,633,488(\mathrm{~S}-\mathrm{S}) .{ }^{37}$

$\mathrm{N}$-[(5Z)-4-(4-Methoxyphenyl)-5H-1,2,3-dithiazol-5-ylidene]- $\mathrm{N}$ phenylamine (12b): $(E)$-1-(4-Methoxyphenyl)ethan-1-one oxime $9 \mathbf{b}^{64}(135 \mathrm{mg}, 1 \mathrm{mmol})$ was treated according to general procedure $\mathrm{C}$ to afford compound $\mathbf{1 2 b}$ as yellow crystals $(81 \mathrm{mg}$, 27\%): m.p. $84-85^{\circ} \mathrm{C}$. Anal. Calcd. for $\mathrm{C}_{15} \mathrm{H}_{12} \mathrm{~N}_{2} \mathrm{OS}_{2}(\%)$ :C, 59.98; $\mathrm{H}, 4.03$; N, 9.33; O, 5.33. Found (\%): C, 60.21; H, 4.22; N, 9.32. ${ }^{1} \mathrm{H} \mathrm{NMR}\left(300 \mathrm{MHz}, \mathrm{CDCl}_{3}\right) \delta: 3.88\left(3 \mathrm{H}, \mathrm{s}, \mathrm{CH}_{3}\right), 6.98(2 \mathrm{H}, \mathrm{d}, J=$ $9.5 \mathrm{~Hz}, \mathrm{Ar}), 7.20(3 \mathrm{H}, \mathrm{m}, \mathrm{Ar}), 7.46(2 \mathrm{H}, \mathrm{d}, J=8.8 \mathrm{~Hz}, \mathrm{Ar}), 8.25$ $(2 \mathrm{H}, \mathrm{d}, J=8.8 \mathrm{~Hz}, \mathrm{Ar}) .{ }^{13} \mathrm{C} \mathrm{NMR}\left(75.5 \mathrm{MHz}, \mathrm{CDCl}_{3}\right) \delta: 55.3\left(\mathrm{CH}_{3}\right)$, $113.5(2 \mathrm{CH}, \mathrm{Ar}), 119.0(2 \mathrm{CH}, \mathrm{Ar}), 129.8(2 \mathrm{CH}, \mathrm{Ar}), 130.6(2 \mathrm{CH}$, $\mathrm{Ar}), 125.3(\mathrm{CH}, \mathrm{Ar}) ; 125.6,153.1,158.4,161.2,165.8\left(5 \mathrm{sp}^{2} \mathrm{C}\right)$. MS (EI, $70 \mathrm{eV}), \mathrm{m} / \mathrm{z}(\%): 300\left(\mathrm{M}^{+}, 25\right), 167(71), 133(100)$. IR $(\mathrm{KBr}), \mathrm{v} / \mathrm{cm}^{-1}: 3088,2956(\mathrm{C}-\mathrm{H}), 2836,1600,1508,1484,1284$, $1172,752,692$.

\section{$\mathrm{N}$-[(5Z)-4-(4-Nitrophenyl)-5H-1,2,3-dithiazol-5-ylidene]- $\mathrm{N}$ -} phenylamine (12c): $(E)-1$-(4-Nitrophenyl)ethan-1-one oxime $9 f^{47}$ $(180 \mathrm{mg}, 1 \mathrm{mmol})$ was treated according to general procedure C to afford compound $12 \mathrm{c}$ as orange crystals ( $85 \mathrm{mg}, 27 \%$ ): m.p. 171-172 ${ }^{\circ} \mathrm{C}$. Anal. Calcd. for $\mathrm{C}_{8} \mathrm{H}_{4} \mathrm{~N}_{2} \mathrm{O}_{2} \mathrm{~S}_{3}(\%)$ : C, 53.32; $\mathrm{H}, 2.88$. $\mathrm{N}, 13.32 ; \mathrm{O}, 10.15$. Found (\%): C, 53.48; $\mathrm{H}, 2.88 ; \mathrm{N}, 13.32 .{ }^{1} \mathrm{H}$ NMR $\left(300 \mathrm{MHz}, \mathrm{CDCl}_{3}\right) \delta: 7.23(3 \mathrm{H}, \mathrm{m}, \mathrm{Ph}), 7.48(2 \mathrm{H}, \mathrm{m}, \mathrm{Ph})$ $8.31(2 \mathrm{H}, \mathrm{d}, J=8.3 \mathrm{~Hz}, \mathrm{Ar}), 8.49(2 \mathrm{H}, \mathrm{d}, J=8.3 \mathrm{~Hz}, \mathrm{Ar}) .{ }^{13} \mathrm{C} \mathrm{NMR}$

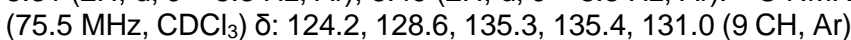
143.5, 153.4, 157.9, 162.5, 164.0 ( $5 \mathrm{sp}^{2}$ tertiary C). MS (El, $\left.70 \mathrm{eV}\right)$, $\mathrm{m} / \mathrm{z}(\%): 315\left(\mathrm{M}^{+}, 13\right), 167(54) . \mathrm{IR}(\mathrm{KBr}), \mathrm{v} / \mathrm{cm}^{-1}: 1612,1600$, $1580,1576,1492,1276,1076,832,756,696 .{ }^{37}$

Ethyl (5Z)-5-(phenylimino)-5H-1,2,3-dithiazole-4-carboxylate (12d): Ethyl (E)-2-(hydroxyimino)propanoate $9 \mathbf{g}^{65}$ (131 $\mathrm{mg}, 1$ $\mathrm{mmol}$ ) was treated according to general procedure $\mathrm{C}$ to afford compound 12d as a red oil (154 mg, 58\%): Anal. Calcd. for $\mathrm{C}_{11} \mathrm{H}_{10} \mathrm{~N}_{2} \mathrm{O}_{2} \mathrm{~S}_{2}(\%): \mathrm{C}, 49.61 ; \mathrm{H}, 3.78 ; \mathrm{N}, 10.52$. Found (\%): C, 49.88; H, 4.02; N, 10.42. ${ }^{1} \mathrm{H}$ NMR $\left(300 \mathrm{MHz}, \mathrm{CDCl}_{3}\right) \delta: 1.43(3 \mathrm{H}$, $\left.\mathrm{t}, J=7.3 \mathrm{~Hz}, \mathrm{CH}_{3}\right), 4.38\left(2 \mathrm{H}, \mathrm{q}, J=7.3 \mathrm{~Hz}, \mathrm{CH}_{2}\right), 7.16(3 \mathrm{H}, \mathrm{m}, \mathrm{Ph})$, $7,46(2 \mathrm{H}, \mathrm{m}, \mathrm{Ph}) .{ }^{13} \mathrm{C}$ NMR $\left(75.5 \mathrm{MHz}, \mathrm{CDCl}_{3}\right) \delta: 14.2\left(\mathrm{CH}_{3}\right), 63.0$ $\left(\mathrm{CH}_{2}\right), 119.3(2 \mathrm{CH}, \mathrm{Ph}), 126.4(\mathrm{CH}), 129.8(2 \mathrm{CH}, \mathrm{Ph}), 139.4$, 152.1, 153.3, 160.4 (4 $\mathrm{sp}^{2}$ tertiary C). MS (El, $\left.70 \mathrm{eV}\right), \mathrm{m} / \mathrm{z}(\%)$ :
$266\left(\mathrm{M}^{+}, 40\right), 167(80) . \mathrm{IR}(\mathrm{KBr}), \mathrm{v} / \mathrm{cm}^{-1}: 3076,2960(\mathrm{C}-\mathrm{H}), 2924$, 2852, $1744(\mathrm{C}=\mathrm{O}), 1700(\mathrm{C}=\mathrm{O}), 1584,1540,1484,1368,1216$, $1144,740,676 . .^{37}$

Ethyl (Z)-2-cyano-2-(4-(4-fluorophenyl)-5H-1,2,3-dithiazol-5ylidene)acetate (13): Sulphur monochloride $(0.32 \mathrm{~mL}, 4 \mathrm{mmol})$ and pyridine $(0.48 \mathrm{~mL}, 6 \mathrm{mmol})$ were successively added dropwise to a solution of $(E)$-1-(4-fluorophenyl)ethan-1-one oxime (9c) $(153 \mathrm{mg}, 1 \mathrm{mmol})$ in dichloromethane $(15 \mathrm{~mL})$ at $-7^{\circ} \mathrm{C}$ under argon. The reaction mixture was kept at $-2^{\circ} \mathrm{C}$ for $20 \mathrm{~min}$ and a solution of ethyl 2-cyanoacetate $(1.13 \mathrm{~g}, 10 \mathrm{mmol})$ in acetonitrile $(10 \mathrm{~mL})$ was added dropwise at $-15^{\circ} \mathrm{C}$ and the resulting mixture was stirred for $1 \mathrm{~h}$. Pyridine $(0.32 \mathrm{~mL}, 4 \mathrm{mmol})$ was added dropwise at $-15{ }^{\circ} \mathrm{C}$, the temperature steadily raised to room temperature and solvent evaporated under reduced pressure. The residue was purified by column chromatography (Silica gel Merck 60 , light petroleum and then light petroleum $-\mathrm{CH}_{2} \mathrm{Cl}_{2}$ mixtures) to afford compound 13 as orange crystals ( $49 \mathrm{mg}, 16 \%$ ): m.p. $188-193^{\circ} \mathrm{C}$. Anal. Calcd. for $\mathrm{C}_{13} \mathrm{H}_{9} \mathrm{FN}_{2} \mathrm{O}_{2} \mathrm{~S}_{2}(\%)$ : C, $50.64 ; \mathrm{H}$, 2.94; F, 6.16; N, 9.09. Found (\%): C 50.49; H 3.10; N 9.12. ${ }^{1} \mathrm{H}$ $\operatorname{NMR}\left(300 \mathrm{MHz}, \mathrm{CDCl}_{3}\right) \delta: 1.38\left(3 \mathrm{H}, \mathrm{t}, J=7.3 \mathrm{~Hz}, \mathrm{CH}_{3}\right), 4.37(2 \mathrm{H}$ $\left.\mathrm{q}, J=7.3 \mathrm{~Hz}, \mathrm{CH}_{2}\right), 7.21(2 \mathrm{H}, \mathrm{t}, J 8.5, \mathrm{Ar}), 7.46(2 \mathrm{H}, \mathrm{m}, \mathrm{Ar}) .{ }^{13} \mathrm{C}$ NMR (75.5 MHz, CDCl 3$) \delta: 14.3\left(\mathrm{CH}_{3}\right), 63.2\left(\mathrm{CH}_{2}\right), 116.1(2 \mathrm{CH})$, 131.5 (2 CH), 90.3, 113.1, 128.6, 162.3, 163.1, 166.3, 167.5 (7 $\left.\mathrm{sp}^{2} \mathrm{C}\right)$. MS (El, $\left.70 \mathrm{eV}\right), \mathrm{m} / \mathrm{z}(\%): 308\left(\mathrm{M}^{+}, 62\right), 235(100), 153(22)$ IR (KBr), v/cm ${ }^{-1}$ : $2928(\mathrm{C}-\mathrm{H}), 2204(\mathrm{CN}), 1664,1520,1444,1280$, $1104,824,792,700$

2-Benzyl-4-phenyl-1,2,5-thiadiazole-3(2H)-thione (14) Benzy amine $(0.109 \mathrm{~mL}, 1 \mathrm{mmol})$ was added to a solution of 4-Phenyl$5 \mathrm{H}-1,2,3-$ dithiazole-5-thione (10a) $(0.106 \mathrm{mg}, 0.5 \mathrm{mmol})$ in THF $(4 \mathrm{~mL})$ at room temperature. The reaction mixture was stirred for $3 \mathrm{~h}$ at room temperature, the alkylammonium hydrogen sulphide was filtered off, and the solvent evaporated under reduced pressure. The residue was purified by column chromatography (Silica gel Merck 60, light petroleum, and then light petroleum $/ \mathrm{CH}_{2} \mathrm{Cl}_{2}$ mixtures) afford compound 14 as a yellow crystalline solid (80 mg, 56\%): m.p. $95-97{ }^{\circ} \mathrm{C}$; Anal. Calcd for $\mathrm{C}_{15} \mathrm{H}_{12} \mathrm{~N}_{2} \mathrm{~S}_{2}$ : C, 63.35; $\mathrm{H}, 4.25 ; \mathrm{N}, 9.85 ; \mathrm{S}, 22.55$. Found (\%): C, $63.45 ; \mathrm{H}, 4.39 ; \mathrm{N}, 10.05 ; \mathrm{S}, 22.68$. $1 \mathrm{H}$ NMR $\left(300 \mathrm{MHz}, \mathrm{CDCl}_{3}\right) \delta$ : $5.31\left(2 \mathrm{H}, \mathrm{s}, \mathrm{CH}_{2}\right), 7.49(8 \mathrm{H}, \mathrm{m}, \mathrm{Ar}), 8.42(2 \mathrm{H}, \mathrm{m}, \mathrm{Ar}) .13 \mathrm{C} \mathrm{NMR}$ $\left(75.5 \mathrm{MHz}, \mathrm{CDCl}_{3}\right)$ ठ: $53.8\left(\mathrm{CH}_{2}\right), 128.1(2 \mathrm{CH}, \mathrm{Ar}), 129.1(2 \mathrm{CH}$, $\mathrm{Ar}), 129.5(2 \mathrm{CH}, \mathrm{Ar}), 129.9(2 \mathrm{CH}, \mathrm{Ar}), 129.9(\mathrm{CH}, \mathrm{Ar}), 130.5(\mathrm{CH}$, $\mathrm{Ar}), 133.0\left(\mathrm{sp}^{2} \mathrm{C}\right), 133.2\left(\mathrm{sp}^{2} \mathrm{C}\right), 160.5\left(\mathrm{sp}^{2} \mathrm{C}\right), 177.4(\mathrm{C}=\mathrm{S})$. MS $(\mathrm{El}, 70 \mathrm{eV}), \mathrm{m} / \mathrm{z}(\%):(\mathrm{M}+, 25), 251(13)$. IR $(\mathrm{KBr}) \mathrm{v} / \mathrm{cm}^{-1}:$ 3064, $2928(\mathrm{C}-\mathrm{H}), 2852,1496,1456,1428,1344,1332,1292,1208$, $1028,848,772,756,708,696 .^{59}$

\section{Acknowledgements}

The authors are grateful to Bloomsbury Colleges - University of London; University College London; University of Zurich; Biocenter Finland/DDCB \& Russian Science Foundation (grant no. 15-13-10022) for financial support towards the goals of our work. We also thank the University of Zurich and the Center for Clinica Studies at the Vetsuisse Faculty for the use of their facilities and the CSC-IT Center for Science Ltd. - Finland, for the allocation of computational resources.

Keywords: Nucleocapsid protein $•$ FIV $•$ HIV-1 • Zinc

Abstraction • Zinc Ejection • Homology Model 


\section{References}

[1] A. J. Leslie, K. J. Pfafferott, P. Chetty, R. Draenert, M. M. Addo, M. Feeney, Y. Tang, E. C. Holmes, T. Allen, J. G. Prado, M. Altfeld, C. Brander, C. Dixon, D. Ramduth, P. Jeena, S. A. Thomas, A St John, T. A. Roach, B. Kupfer, G. Luzzi, A. Edwards, G. Taylor, H. Lyall, G. Tudor Williams, V. Novelli, J. Martinez-Picado, P. Kiepiela, B. D. Walker, P. J. R. Goulder, Nat Med. 2004, 10, 282-289.

[2] 2013 Report on the Global AIDS Epidemic; UNAIDS: Geneva, Switzerland 2013

[3] J. H. Elder, Y-C. Lin, E. Fink, C. K. Grant, Curr. HIV Res. 2010, 8, 73-80.

[4] N. C. Pedersen, E. W. Ho, M. L. Brown, J. K. Yamamoto, Science. 1987 235, 790-793

[5] T. Hatziioannou, D. T. Evans, Nat. Rev. Microbiol. 2012, 10, 852-867.

[6] E. Remy, H. de Rocquigny, P. Petitjean, D. Muriaux, V. Theilleux, J. Paoletti, B. P. Roques, J. Biol. Chem. 1998, 273, 4819-4822.

[7] L. Rong, C. Liang, M. Hsu, L. Kleiman, P. Petitjean, H. de Rocquigny, B. P. Roques, M. A. Wainberg, J. Virol. 1998, 72, 9353-9358.

[8] Y. Zhang, H. Qian, Z. Love, E. J. Barklis, J. Virol. 1998, 72, 1782-1789.

[9] S. Carteau, S. C. Batson, L. Poljak, J. F. Mouscadet, H. de Rocquigny, J. L. Darlix, B. P. Roques, E. Käs, C. Auclair. J. Virol. 1997, 71, 6225 6229

[10] G. Mirambeau, S. Lyonnais, D. Coulaud, L. Hameau, S. Lafosse, J. Jeusset, I. Borde, M. Reboud-Ravaux, T. Restle, R. J. Gorelick, E. Le Cam, PLoS One. 2007, 7, e669.

[11] V. Tanchou, D. Decimo, C. Péchoux, D. Lener, V. Rogemond, L. Berthoux, M. Ottmann, J. L. Darlix, J. Virol. 1998, 72, 4442-4447.

[12] S. Ramboarina, Druillennec, N. Morellet, S. Bouaziz, B. P. Roques, J. Virol. 2004, 78, 6682-6687.

[13] T. Matsui, Y. Kodera, E. Miyauchi, H. Tanaka, H. Endoh, H. Komatsu, T. Tanaka, T. Kohno, T. Maeda, Biochem. Biophys. Res. Commun. 2007 358, 673-678.

[14] M. L. Manrique, M. L. Rauddi, S. A. González, J. L. Affranchino, J. Virol. 2004, 327, 83-92.

[15] N. Morellet, H. Meudal, S. Bouaziz, B. P. Roques, Biochem. J. 2006, 393, 725-732.

[16] P. Amodeo, M. A. Castiglione-Morelli, A. Ostuni, G. Battistuzzi, A. Bavoso, Biochemistry. 2006, 45, 5517-5526.

[17] J. L. Darlix, M. Lapadat-Tapolsky, H. de Rocquigny, B. P. Roques, J. Mol. Biol. 1995, 254, 523-537.

[18] H. Demene, C. Z. Dong, M. Ottmann, M. C. Rouyez, N. Jullian, N. Morellet, Y. Mely, J. L. Darlix, M. C. Fournie-Zaluski, S. Saragosti, B. P. Roques, Biochemistry. 1994, 33, 11707-11716.

[19] R. J. Gorelick, T. D. Gagliardi, W. J. Bosche, T. A. Wiltrout, L. V. Coren, D. J. Chabot, J. D. Lifson, L. E. Henderson, L. O. Arthur, Virology. 1999 256, 92-104.

[20] D. Garg, B. E. Torbett, Virus Res. 2014, 193, 135-143.

[21] M. Mori, A. Nucci, M. C. Lang, N. Humbert, C. Boudier, F. Debaene, S. Sanglier-Cianferani, M. Catala, P. Schult-Dietrich, U. Dietrich, C. Tisné Y. Mely, M. Botta, ACS Chem Biol. 2014, 9, 1950-1955.

[22] W. G. Rice, J. G. Supko, L. Malspeis, R. W. Jr. Buckheit, D. Clanton, M. Bu, L. Graham, C. A. Schaeffer, J. A. Turpin, J. Domagala, R. Gogliotti, J. P. Bader, S. M. Halliday, L. Coren, R. C. 2nd. Sowder, L. O. Arthur, L. E. Henderson, Science. 1995, 270, 1194-1197.

[23] J. A. Turpin, Y. Song, J. K. Inman, M. Huang, A. Wallqvist, A. Maynard, D. G. Covell, W. G. Rice, E. Appella. J. Med. Chem. 1999, 42, 67-86.

[24] C. Pannecouque, B. Szafarowicz, N. Volkova, V. Bakulev, W. Dehaen, Y. Mély, D. Daelemans, Antimicrob Agents Chemother. 2010, 54, 1461 1468.

[25] J. A. Loo, T. P. Holler, J. Sanchez, R. Gogliotti, L. Maloney, M. D. Reily, J. Med. Chem. 1996, 39, 4313-4320.

[26] W. G. Rice, C. A. Schaeffer, L. Graham, M. Bu, J. S. Mcdougal, S. L. Orloff, F. Villinger, M. Young, S. Oroszlan, M. R. Feseni, Y. Pommier, J. Mendeleyev, E. Kun, Proc. Natl. Acad. Sci. USA 1993, 90, 9721-9724.

[27] W. G. Rice, J. A. Turpin, M. Huang, D. Clanton, R. W. Jr. Buckheit, D. G. Covell, A. Wallqvist, N. B. McDonnell, R. N. DeGuzman, M. F. Summers, L. Zalkow, J. P. Bader, R. D. Haugwitz, E. A. Sausville, Nat Med. 1997 3, 341-345.

[28] A. Mayasundari, W. G. Rice, J. B. Diminniea, D. C. Bakera, Bioorg. Med. Chem. 2003, 11, 3215-3219.

[29] T. Vercruysse, B. Basta, W. Dehaen, N. Humbert, J. Balzarini, F. Debaene, S. Sanglier-Cianférani, C. Pannecouque, Y. Mély, D Daelemans, Retrovirology. 2012, 9:95.

[30] L. Sancineto, A. Mariotti, L. Bagnoli, F. Marini, J. Desantis, N. Iraci, C. Santi, C. Pannecouque, O. Tabarrini. J. Med. Chem., 2015, 58, 9601 9614.

[31] C. R. M. Asquith, M. L. Meli, L. S. Konstantinova, T. Laitinen, M. Peräkylä, A. Poso, O. A. Rakitin, K. Allenspach, R. Hofmann-Lehmann, S. T. Hilton, Bioorg. Med. Chem. Lett. 2014, 24, 2640-2644.
[32] C. R. M. Asquith, M. L. Meli, L. S. Konstantinova, T. Laitinen, A. Poso, O. A. Rakitin, K. Allenspach, R. Hofmann-Lehmann, S. T. Hilton. Bioorg. Med. Chem. Lett. 2015, 25, 1352-1355.

[33] G. Cottenceau, T. Besson, V. Gautier, C. W. Rees, A.-M. Pons, Bioorg Med. Chem. Lett. 1996, 6, 529-532.

[34] T. Besson, C. W. Rees, G. Cottenceau and A.-M. Pons, Bioorg. Med. Chem. Lett. 1996, 6, 2343-2348.

[35] R. W. Joseph, D. L. Antes, P. Osei-Gyimah, US 5688744, 1997.

[36] V. Thiéry, C. W. Rees, T. Besson, G. Cottenceau, A.-M. Pons, Eur. J. Med. Chem. 1998, 33, 149-153.

[37] L. S. Konstantinova, O. I. Bol'shakov, N. V. Obruchnikova, H. Laborie, A V. Sopéna, I. Lanneluc, L. Picot, S. Sablé, V. Thiéry, O. A. Rakitin, Bioorg. Med. Chem. Lett. 2009, 19, 136-141.

[38] F. Oppedisano, M. Catto, P. A. Koutentis, O. Nicolotti, L. Pochini, M. Koyioni, A. Introcaso, S. S. Michaelidou, A. Carotti, C. Indiveri, Toxicol. Appl. Pharmacol., 2012, 265, 93-102.

[39] J. E. Moore. US 4059590, 1977.

[40] J. E. Moore. US 4119722, 1978.

[41] R. Appel, H. Janssen, I. Haller, M. Plempel. DE 2848221, 1980.

[42] R. Mayer, E. Förster, B. D. Matauschek. DD 212387, 1984

[43] J. Benting, P. Dahmen, U. Wachendorff-Neumann, H. Hadano, J.-P. Vors, WO 2012045726, 2012.

[44] A. Charalambous, M. Koyioni, I. Antoniades, D. Pegeioti, I. Eleftheriou S. S. Michaelidou, S. A. Amelichev, L. S. Konstantinova, O. A. Rakitin, P A. Koutentis, P. A. Skourides, Med. Chem. Commun., 2015, 6, 935-946.

[45] L. S. Konstantinova, O. A. Rakitin, Russ. Chem. Rev. 2008, 77, 521-546.

[46] R. Appel, H. Janssen, M. Siray, F. Knoch. Chem. Ber. 1985, 118, 1632 1643

[47] P. A. Koutentis, Molecules. 2005, 10, 346-359.

[48] V. V. Popov, O. I. Bol'shakov, L. S. Konstantinova, O. A. Rakitin, Russ. Chem. Bull. 2009, 58, 437-441.

[49] J. K. Augustine, R. Kumar, A. Bombrun, A. B. Mandal, Tetrahedron Lett. 2011, 52, 1074-1077.

[50] K. Kim, Sulfur. Rep. 1998, 21, 147-207.

[51] P. W. Sylvester, Methods Mol. Biol. 2011, 716, 157-168.

[52] R. A. Crandell, C. G. Fabricant, W A. Nelson-Rees, In Vitro. 1973, 9, 176 185.

[53] J. K. Yamamoto, C. D. Ackley, H. Zochlinski, H. Louie, E. Pembroke, M. , H. Hansen, R. Munn, T. Okuda, Intervirology. 1991, 32, 361-375.

[54] D. Klein, C. M. Leutenegger, C. Bahula, P. Gold, R. Hofmann-Lehmann B. Salmons, H. Lutz, W. H. Gunzburg, J. Acquir. Immune. Defic. Syndr 2001, 26, 8-20.

[55] L. Pauling, J. Am. Chem. Soc. 1932, 54, 3570-3582.

[56] L. R. Bisset, H. Lutz, J. Böni, R. Hofmann-Lehmann, R. Lüthy, J. Schüpbach, J. Antiviral. Res. 2002, 53, 35-45.

[57] V. Summa, A. Petrocchi, F. Bonelli, B. Crescenzi, M. Donghi, M. Ferrara, F. Fiore, C. Gardelli, O. Gonzalez Paz, D. J. Hazuda, P. Jones, O. Kinzel, R. Laufer, E. Monteagudo, E. Muraglia, E. Nizi, F. Orvieto, P. Pace, G Pescatore, R. Scarpelli, K. Stillmock, M. V. Witmer, M. Rowley, J. Med. Chem. 2008, 51, 5843-5855.

[58] L. S. Konstantinova, O. I. Bol'shakov, N. V. Obruchnikova, S. P. Golova, Y. V. Nelyubina, K. A. Lyssenko, O. A. Rakitin, Mendeleev. Commun. 2009, 19, 84-86

[59] L. S. Konstantinova, O. I. Bol'shakov, N. V. Obruchnikova, S. P. Golova Y. V. Nelyubina, K. A. Lyssenko, O. A. Rakitin, Tetrahedron. 2010, 66, 4330-4338.

[60] K. M. Cook, S. T. Hilton, J. Mecinovic, W. B. Motherwell, W. D. Figg, C. J. Schofield, J. Biol. Chem. 2009, 284, 26831-26838.

[61] C. Woodcock, W. Henderson, C. O. Miles, J. Inorg. Biochem. 2001, 5, 187-199.

[62] J. C. Woodcock, W. Henderson, C. O. Miles. B. K. Nicholson, J. Inorg Biochem. 2001, 84, 225-232.

[63] S. Bourbigot, N. Ramalanjaona, C. Boudier, G. F. Salgado, B. P. Roques Y. Mely, S. Bouaziz, N. J. Morellet, J. Mol. Biol. 2008, 383, 1112-1128.

[64] M. Y. Wani, F. Athar, A. Salauddin, S. M. Agarwal, A. Azam, I. Choi, A R. Bhat, Eur. J. Med. Chem. 2011, 46, 4742-4752.

[65] S. Wolfe, C. Akuche, S. Ro, W. Marie-Claire, K. Chan-Kyung, S. Zheng Can. J. Chem. 2003, 81, 915-936. 


\section{Entry for the Table of Contents}

\section{FULL PAPER}

Introduction

Results and Discussion

Conclusions

Experimental

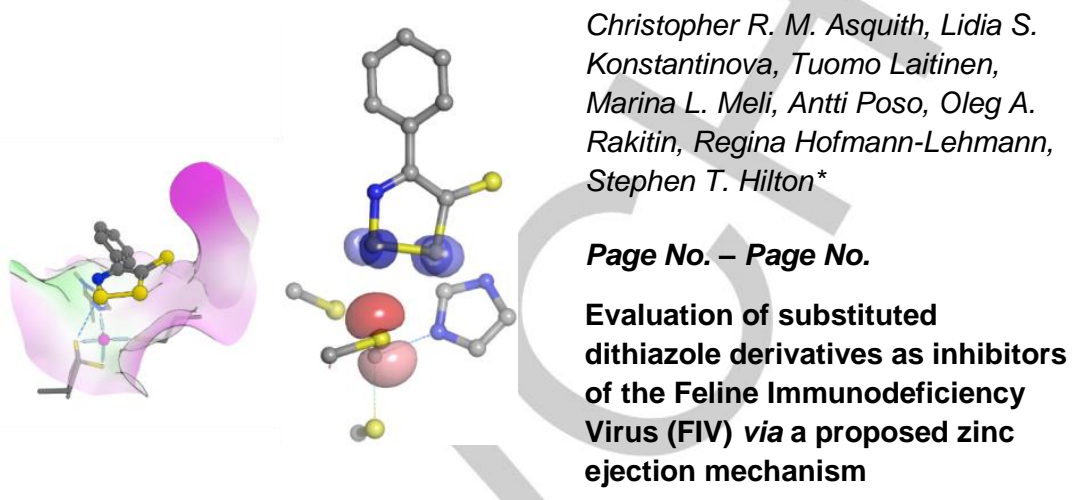

Christopher R. M. Asquith, Lidia S. Konstantinova, Tuomo Laitinen, Marina L. Meli, Antti Poso, Oleg A. dithiazole derivatives as inhibitors of the Feline Immunodeficiency ejection mechanism

A diverse library of 1,2,3-dithiazole derivatives have been synthesized and tested against Feline Immunodeficiency Virus (FIV) in cells using Density Functional Theory (DFT) to determine a degree of suitability in a simplified nucleocapsid homology model. The compounds displayed nanomolar activity and relatively low toxicity and represent a new class of compounds for the treatment of FIV and HIV. This work demonstrates the versatility of the of 1,2,3-dithiazole scaffold, adding anti-viral abilities to the portfolio of biological activities already known for this class of compound. 